\title{
IAMJ
}

INTERNATIONAL

AYURVEDIC

MEDICAL JOURNAL

\section{EFFICACY OF YOGA MODALITIES IN BOOSTING IMMUNITY IN FRONT LINE HEALTH CARE WORKERS}

\author{
Komal Gupta $^{1}$, Ankur Singhal ${ }^{2}$ \\ ${ }^{1}$ M.D. Swasthwritt (Scholar), Vaidya Yagya Dutt Sharma Ayurveda Mahavidyalaya, Khurja, Bulandshahr, \\ Uttar Pradesh, India \\ ${ }^{2}$ M.D. Kayachikitsa, ${ }^{2}$ Medical Superintendent, GS Ayurveda Medical College \& Hospital, Pilkhuwa, Hapur, \\ Uttar Pradesh, India
}

Corresponding Author: drkomalgupta2016@gmail.com

https://doi.org/10.46607/iamj0608092020

(Published online: September 2020)

Open Access

(C) International Ayurvedic Medical Journal, India 2020

Article Received: 11/08/2020 - Peer Reviewed: 12/09/2020 - Accepted for Publication: 12/09/2020

Check for updates

\section{ABSTRACT}

Introduction: Today World is facing a major financial setback and health emergency due to one of the communicable diseases COVID-19. As impact of communicable diseases is increasing day by day and role of modern treatment is decreasing, it seems very difficult to stop the spread of such disease as we have numerous densely populated cities, sub urban areas, slums etc. and poor nutritional conditions in India. As front-line health care workers are most exposed, it becomes more difficult for them to work in such environment. They need to take care of patients as well as for themselves by taking proper preventive measures. As 'Ayurveda' an ancient old science, well explains about preventive and immunity boosting principles, everyone is looking towards Ayurveda for an effective solution to handle such situations. In the view of above points this research was carried out to assess the efficacy of Yoga modalities in boosting immunity against such communicable diseases in front line health care workers. The research was carried with three parameters which plays significant role in maintaining immunity and keeping us healthy and fit i.e. Ahara Shakti, Vyayama Shakti, Mansika Shakti.

Material Methods: The study was carried out in 40 health care workers of GS Hospital and GS Ayurveda Hospital, Pilkhuwa. Yoga intervention was carried out in all the health care workers for 30 days. Ahara Shakti, Vyayam Shakti 
and Mansik Shakti were assessed before and after yoga intervention and results were assessed statistically with student ' $\mathrm{t}$ ' test.

Results \& Conclusion: Difference in Results before and after treatment was found significant in almost all the cases. Improvement seen on pain intolerance and grand meal was not significant. Here it can be concluded that yoga modalities help to improve sarta, bala and vyadhikshamatwa (Immunity).

Keywords: Ahara Shakti, Vyayama Shakti, Mansika Shakti, Sarta, Bala, Vyadhikshamatwa

\section{INTRODUCTION}

Health is never an issue until someone gets sick; it is the reality in current situation. Because of improper diet, lack of exercise, stress, low quality of food grains $\&$ global warming, overall health status of individuals is poor \& they are getting easily prone to communicable diseases, COVID-19 pandemic is the best example. They are big challenges \& creating a burden over health care system. Ayurveda though an ancient medical science has clearly described such communicable diseases \& their cause, mode of transmission, prevention as well as cure. Charak has quoted Janapado dhwansa, (mass destruction) \& its 4 reasons as dushita (polluted) vayu (Air), jala (Water), kala (time), desh (region). Sushrut has already mentioned aupsargika rogas (communicable diseases) i.e. kushtha (Skin diseases), jwara (Fever) etc. \& their mode of transmission.

Prevention as well as cure of disease is goal of Ayurveda. Through maintenance of Dincharaya, Rutucharya, Sadvritta, ours physical and mental health can be secured and with the help of Panchakarma,
Aushadha, \& Rasayana these diseases can be cured. Yoga also plays a significant role in balance of body and mind and ultimately health. ${ }^{1}$ Previous researches also indicate that Yoga plays a significant role in enhancing immunity. When our body and mind are under any type of stress, our immune system is compromised, leading to chronic inflammation. Chronic inflammation leads to many health problems. And it has been proved that Yoga can 'down regulate pro-inflammatory markers. ${ }^{2}$ In the view of above points this research was conducted to assess the efficacy of Yoga Modalities following Ayurveda principles, to boost the bala in terms of immunity in front line health care workers.

Objectives: To assess the efficacy of Yoga Modalities in boosting immunity in Front line Health care workers.

Methodology: Sample: Minimum 40 health care workers randomly selected from GS Ayurveda Hospital and GS Hospital, Pilkhuwa, Hapur, Uttar Pradesh.

Yoga Modalities: Suryanamaskar, Anulom vilom, Bhastrika, Pawan Mukta Asana, Vajra asana, Dhyana

Table 1: Yoga Modalities

\begin{tabular}{|l|l|l|l|}
\hline Yoga & Duration & Frequency & Before Food/ After Food \\
\hline Surya namaskar & 10 cycles & Two times a day (Morning \& evening) & Before Food \\
\hline Anulom Vilom & 30 cycles & Two times a day (Morning \& evening) & Before Food \\
\hline Bhastrika & 30 cycles & Two times a day (Morning \& evening) & Before Food \\
\hline Pawan Mukta Asana & 5 cycles & Two times a day (Morning \& evening) & Before food \\
\hline Vajra Asana & $5 \mathrm{~min}$ & Three Times a day & After Food \\
\hline Dhyana & $15 \mathrm{~min}$ & Two times a day (Morning \& evening) & Before Food \\
\hline
\end{tabular}

\section{Exclusion Criteria}

- Cases suffering from any co morbidities.

- Age below 20 or above 40 yrs.
- Cases those are symptomatic to any major systemic disease or communicable disease. 


\section{Inclusive criteria}

- Age: above 20 yrs. or below 40 yrs. of either sex.

- Asymptomatic, front line health care workers.

\section{Assessment Criteria:}

Table 2: Parameters

\begin{tabular}{|l|l|l|}
\hline S.No. & \multirow{2}{*|}{} & Subjective Parameters \\
\hline $\mathbf{1}$ & \multirow{2}{*}{ Manasik Shakti } & Satwa Sarta \\
\hline $\mathbf{2}$ & & Pain Tolerance \\
\hline $\mathbf{3}$ & & Mansik Bhava \\
\hline $\mathbf{4}$ & \multirow{2}{*}{ Ahara Shakti } & Abhyavaran shakti \\
\hline $\mathbf{5}$ & & Grand meal \\
\hline $\mathbf{6}$ & & Jarana Shakti \\
\hline $\mathbf{7}$ & Vyayama & Vyayama Shakti \\
\hline $\mathbf{8}$ & Shakti & Stepping Exercise $(P R)$ \\
\hline $\mathbf{9}$ & & Stepping Exercise $(R R)$ \\
\hline
\end{tabular}

Ahara Shakti, Vyayama Shakti and Manasik Shakti before Yoga intervention and after 30 days of intervention. Health workers were assessed for any sign and symptoms of any communicable disease every 3rd day.

Diet and lifestyle: According to Ayurveda principles,

Statistical Analysis: Student ' $t$ ' test

\section{Observations and Results}

Table 3: Distribution of Health workers according to Age

\begin{tabular}{|l|l|l|}
\hline Age in yrs & Participants & $\%$ \\
\hline $20-25$ & 10 & 25 \\
\hline $26-30$ & 12 & 30 \\
\hline $31-35$ & 10 & 25 \\
\hline $36-40$ & 8 & 20 \\
\hline Total & 40 & 100 \\
\hline
\end{tabular}

Table 4: Distribution of Health workers according to Sex

\begin{tabular}{|l|l|l|}
\hline Gender & Participants & $\%$ \\
\hline Female & 24 & 60 \\
\hline Male & 16 & 40 \\
\hline Total & 40 & 100 \\
\hline
\end{tabular}

Table 5: Distribution of Health workers according to Diet

\begin{tabular}{|l|l|l|}
\hline Diet & Participants & $\%$ \\
\hline Mix & 33 & 82.5 \\
\hline Veg & 7 & 17.5 \\
\hline Total & 40 & 100 \\
\hline
\end{tabular}

Table 6: Distribution Of Health workers according to KOSTHA

\begin{tabular}{|l|l|l|}
\hline Koshtha & Participants & $\%$ \\
\hline Krura & 17 & 42.5 \\
\hline Madhyam & 18 & 45 \\
\hline Mrudu & 5 & 12.5 \\
\hline Total & 40 & 100 \\
\hline
\end{tabular}


Table 7: Distribution of Health workers according to $A G N I$

\begin{tabular}{|l|l|l|}
\hline Agni & Participants & $\%$ \\
\hline Mandagni & 6 & 15 \\
\hline Madhyagni & 10 & 25 \\
\hline Vishamagni & 24 & 60 \\
\hline Total & 40 & 100 \\
\hline
\end{tabular}

Table 8: Distribution of Health workers according to Vishamashana

\begin{tabular}{|l|l|l|}
\hline Vishamashana & Participants & $\%$ \\
\hline Never & 9 & 22.5 \\
\hline Sometimes & 20 & 50 \\
\hline Always & 11 & 27.5 \\
\hline Total & 40 & 100 \\
\hline
\end{tabular}

Table 9: Distribution of Health workers according to Exercises

\begin{tabular}{|l|l|l|}
\hline Exercises & Participants & $\%$ \\
\hline Never & 14 & 35 \\
\hline Sometimes & 26 & 65 \\
\hline Always & 0 & 0 \\
\hline Total & 40 & 100 \\
\hline
\end{tabular}

Table 10: Results

\begin{tabular}{|l|l|l|l|l|l|l|l|}
\hline S.No. & & $\begin{array}{l}\text { Subjective } \\
\text { Parameters }\end{array}$ & BT & AT & t-value & p-value & $\begin{array}{l}\text { S/NS } \\
\text { Significance Level }\end{array}$ \\
\hline $\mathbf{1}$ & \multirow{2}{*}{ Manasik } & Satwa Sarta & 4.5 & 4.93 & 3.122 & 0.00169 & Significant \\
\hline $\mathbf{2}$ & Shakti & Pain Tolerance & 3.2 & 3.3 & 1.778247 & 0.04158 & Not Significant \\
\hline $\mathbf{3}$ & & Mansik Bhava & 3.37 & 4.4 & 6.904105 & $<.00001$ & Significant \\
\hline $\mathbf{4}$ & \multirow{2}{*}{ Ahara } & Abhyavaran shakti & 3.61 & 5.12 & 11.590226 & $<.00001$ & Significant \\
\hline $\mathbf{5}$ & \multirow{2}{*}{ Shakti } & Grand meal & 4.2 & 4.4 & 1.778247 & .04158 & Not Significant \\
\hline $\mathbf{6}$ & & Jarana shakti & 4 & 5.4 & 8.573214. & $<.00001$ & Significant \\
\hline $\mathbf{7}$ & \multirow{2}{*}{ Vyayama } & Vyayama Shakti & 3.22 & 4.73 & 11.590226 & $<.00001$ & Significant \\
\hline $\mathbf{8}$ & \multirow{2}{*}{ Shakti } & Stepping Exercise (PR) & 3.22 & 4.44 & 7.705737 & $<.00001$ & Significant \\
\hline $\mathbf{9}$ & & Stepping Exercise (RR) & 3.22 & 4.68 & 8.735236 & $<.00001$ & Significant \\
\hline
\end{tabular}

The research "Efficacy of Yoga modalities in boosting immunity in Front line Health care workers" was carried out in 40 health care workers. Yoga modalities showed significant results in Satwa Sarta, Mansik Bhava, Abhyawaran Shakti and Jaran Shakti and Vyayam Shakti. Results on Pain Intolerance and Grand meal were found insignificant.

\section{DISCUSSION}

Ayurveda has propounded the concept of immunity as Vyadhikshamatwa ${ }^{3}$. Acharya Chakrapanidatta has interpretated the term Vyadhi-kshamatwa as Vyadhi bala Virodhitwa i.e., antagonistic to the strength and virulence of the disease and Vyadhyutpada Pratibandhakatwa i.e., the capacity to inhibit and bind the causes and factors of the disease ${ }^{4}$. The Bala of the body is the base of life; it depends upon the astavidh sarta of the body ${ }^{5}$. Sarta indicates the health of all the dhatus of the body. So bala covers all areas of humans because it is the conjugative expression in the form of physical strength, psychological strength and immune strength of body. Bala is essential for healthy body \& 
mind. In patients it is the factor which will decide the virulence of disease by providing the immunity to body. So, it is essential to judge the level of Bala in the body before considering the patient under treatment ${ }^{6}$. Bala of the body in short can be assessed in terms of Ahara shakti, Vyayaym shakti and Mansik shakti. In terms of modern science by assessing Ahara Shakti we can assess the health of digestive system, by assessing Vyayam Shakti we can assess the health of cardiovascular system, locomotor system and respiratory system and by assessing Mansik Shakti we can assess the nervous system. So Ahara Shakti, Vyayam Shakti and Mansik Shakti is the assessment of all the major systems of the body. And the good health of all the systems reflects overall immunity of the body. Yoga exercises balances Mansik dosha and Sharirik dosha and set a coordination to improve and maintain health. And healthy individual achieves natural bala and vyadhikshamatwa.

\section{CONCLUSION}

Yoga modalities for 30 days in front line health care works showed significant improvement in Mansik shakti, Ahara shakti and Vyayama shakti. This can be concluded that yoga modalities help in improving Bala, Dhatu Sarata and ultimately Vyadhikshamatwa i.e. immunity.

\section{REFERENCES}

1. Soumya Kanti Biswas and Monojit Debnath, Yoga and Ayurveda: Concomitant preventive therapeutics for some important lifestyle disorders, Indian Journal of traditional knowledge, Vol 16(Suppl.), June 2017, pp. S60-S68

2. R I Falkenberg, C Eising, M L Peters, Yoga and immune system functioning: a systematic review of randomized controlled trials, PMID: 29429046 DOI: 10.1007/s10865-018-9914-y

3. Rajagopala S, Ashok BK and Ravishankar B: Immunomodulatory activity of Vachadhatryadi Avaleha in albino rats. Ayu. 2011 Apr-Jun; 32(2):275-278.

4. Tripathi JS, Singh RH: The Concept and Practice of Immunomodulation in Ayurveda and the Role of Rasayanas as Immunomodulators. Ancient Science of Life 1999 Jul, Aug, Sep, Oct;19(1\&2):59-63.
5. Dr. Gangashaya Pandey, Dr. Brahmanand Tripathi, Charak Samhita -Vol-1, Chukhambha Subharti Prakashan, Varanasi, Reprint Edition 2009, Vimana Sthana 8/102, pp:763

6. Agnivesh, Caraka, DrdhaBala - Caraka Samhita, Sanskrit Commentary Ayurveda- Dipika by Chakrapanidutta Edited by Vaidya jadavaji Trikamji Acharya, Chaukhamba Surabharti Prakshan, Varanasi, (Ch. Vi-8/94), Reprint-2005: 276.

\section{Source of Support: Nil \\ Conflict of Interest: None Declared}

How to cite this URL: Komal Gupta \& Ankur Singhal: Efficacy Of Yoga Modalities In Boosting Immunity In Front Line Health Care Workers. International Ayurvedic Medical Journal \{online\} 2020 \{cited September, 2020\} Available from: http://www.iamj.in/posts/images/upload/4337 4341.pdf 